\title{
Use of long-acting progesterone to acyclic embryo recipient mares
}

\author{
Gabriel Maksoud Greco ${ }^{1}$, Fábio Luis Gonçalves Burlamaqui ${ }^{1}$, Aline Emerim Pinna ${ }^{1}$, Fernando \\ José Rohen de Queiroz ${ }^{2}$, Maria Pia dos Santos Cunha ${ }^{1}$, Felipe Zandonadi Brandão ${ }^{1}$
}

\footnotetext{
1 Universidade Federal Fluminense, Faculdade de Veterinária, Niterói, RJ, Brazil.

2 Clínica Veterinária Equus, Itaboraí, RJ, Brazil.
}

\begin{abstract}
The objective of this study was to evaluate the efficiency of cyclic and acyclic progesterone-treated recipient mares in a commercial embryo transfer program. Acyclic recipients were treated with decreasing amounts of estradiol cypionate $\left(\mathrm{ECP}^{\circledR}\right.$ - Pfizer Saúde Animal, São Paulo, Brazil), followed by $1500 \mathrm{mg}$ of a sustained-release progesterone injection (P4LA150 ${ }^{\circledR}$ - Laboratórios B.E.T., Rio de Janeiro, Brazil). Out of all 1506 embryo recovery attempts performed, 59.36\% were positive (894/1506). Pregnancy rates of cyclic and acyclic mares were, respectively, 44.12\% (319/723) and 57.68\% (139/241) - higher in acyclic recipients under progesterone treatment. Embryo loss was similar between groups (9.72\% $31 / 319$ vs. $11.51 \%$ - 16/139). When fertility data on acyclic mares treated with long-action progesterone were grouped in relation to the interval of the beginning of the treatment with progesterone to the embryo transfer, there was no difference in pregnancy rates at 12 days (51.28\% - 20/39; 58.92\% - 33/56; 60.52\% - 46/76 and 58.57\% - 41/70 for embryos transferred 3 (P3), 4 (P4), 5 (P5) and 6 (P6) days after the beginning of the treatment with progesterone). Groups P3, P4, P5 and P6 showed embryo loss rates of $20.00 \%$ (4/20), $12.12 \%$ (4/33), $2.17 \%$ (1/46) and $17.07 \%(7 / 41)$, respectively. These rates were similar in groups P3, P4 and P6. Pregnant recipients submitted to an embryo transferring procedure on P5 showed lower embryo mortality rates than on P3 and P6. P4 recipients tended to suffer higher embryo mortality rates than P5. Acyclic recipient mares under progesterone treatment can be satisfactoryly used in embryo transfer programs.
\end{abstract}

Key Words: embryo loss, embryo transfer, mare, pregnancy

\section{Introduction}

In Brazil, equine embryo transfer has been facing growing interest since the first national studies were published (Fleury et al., 1987; Henry et al., 1987). Nowadays, Brazil is one of the main countries in number of annual successful transfers (Losinno \& Alvarenga, 2006).

It is known that success rates after an embryo transfer procedure are affected by many factors such as those related to donors and recipients, semen used, embryo quality, manipulation and storage, transfer technique and climatic conditions (Squires et al., 1999; Carnevale et al., 2000).

In order to obtain satisfactory results, it is essential that progesterone act on the reproductive tract of recipient mares (Mckinnon et al., 1988a; Fleury, 2002). Progesterone is the only ovarian hormone necessary to maintain an early pregnancy in the equine species (Wilker et al., 1991; Goff, 2002). Ovariectomized or acyclic mares under hormonal treatment can be successfully used as embryo recipients (Hinrichs et al., 1985; Carnevale et al. 2000; Riera et al., 2008). The use of recipients either in anestrous or transition allows embryo transfer programs to start earlier and finish a couple months later, for the period recipients show cyclic activity is short, compared with donors. In this matter, the use of progesterone-treated acyclic mares reduces the need for ovulation synchronization between donors and recipients, requiring less frequent reproductive evaluations (Rocha Filho et al., 2004).

In Brazil, treatment of acyclic recipients with longacting progesterone has been routinely conducted in commercial equine embryo transfer programs. However, more studies focusing the major obstacles to its success are necessary: low post-transfer pregnancy rates and high embryo mortality rates.

The present study aimed to evaluate the efficiency of a commercial equine embryo transfer program using cyclic and long-acting progesterone-treated acyclic recipients. The authors assumed that long-acting progesterone-treated acyclic and cyclic recipients have similar pregnancy and embryo mortality rates and that the interval between the onset of long-acting progesterone treatment and embryo transfer does not affect either pregnancy or embryo mortality rates. 


\section{Material and Methods}

This study was conducted in a commercial equine embryo transfer clinic, Clínica Equus Veterinária, located in Itaboraí city, Rio de Janeiro State, Brazil (latitude $22^{\circ} 44^{\prime} 40$ " S; longitude $42^{\circ} 51^{\prime} 34^{\prime \prime} \mathrm{O}$ and 46 meters of altitude). Data concerning reproductive activities between July 2005 and March 2008 were recorded. Campolina breed stallions, donors (average $14.8 \pm 3.1$ of age) and recipients were resident at the clinic. Throughout this period, animals were submitted to constant management conditions. Embryo recovery, handling and transfer, as well as recipient selection, were performed by the same veterinarian.

Donor mares were daily evaluated through rectal palpation and ultrassonography (Aloka ${ }^{\circledR}$ SSD-500, Aloka Co., Japan), beginning four days after an embryo recovery attempt. Reproductive characteristics such as follicle diameter, uterine tone and grade of endometrial edema were monitored.

Donor mares showing follicles $\geq 35$ milimeters (mm) were either artificially inseminated in alternate days until an ovulation occurred or treated with a single endovenous injection containing 2000 international units (IU) of human chorionic gonadotrophin (hCG, Vetecor $5000^{\circledR}$ - Hertape Calier Saúde Animal, Juatuba, MG, Brazil) and artificially bred until six hours post-ovulation. hCG was used to reduce the number of inseminations and to synchronize ovulations between donors and recipients.

Mares were artificially bred with either fresh or cooled semen, with at least 500 million progressively motile spermatozoa, placed at their uterine body. Upon detection of intrauterine fluid 48 hours post-insemination, donors were flushed with two or more liters of lactated ringers solution and intramuscularly injected with $2.5 \mathrm{mg} / \mathrm{kg}$ of enrofloxacin (Flotril ${ }^{\circledR}$ - Schering-Plough, Cotia, SP, Brazil) and 20 IU of oxytocin (Placentina ${ }^{\circledR}$ - U.C.B. Saúde Animal, Jaboticabal, SP, Brazil). Donors were once more evaluated 24 hours after their first ovulation, in order to detect multiple synchronic ovulations.

On the eight day post-ovulation, embryos were recovered using the method described by Squires et al. (1999). At the end of the embryo recovery uterine flush, mares were intramuscularly injected with 10 miligrams (mg) of dinoprost tromethamine (Lutalyse ${ }^{\circledR}$ - Pfizer Saúde Animal, São Paulo, SP, Brazil).

Using a binocular stereo microscope (Nikon ${ }^{\circledR}$ SMZ 645, Nikon Co., Japan), embryos were identified, drawn into a 0.5-mL sterile semen straw and placed on a sterile Petri dish containing nine droplets of embryo holding solution (Emcare $^{\circledR}$ - ICP, Auckland, New Zeland). Embryos were washed by clockwise transfer through these droplets. A new $0.5-\mathrm{mL}$ sterile semen straw was used every three transfers. Embryos were classified according to McKinnon \& Squires (1988b) (Table 1).

Follicular development and reproductive characteristics were monitored in recipient mares as previously described for donors. Estrous recipients were daily evaluated until an ovulation occurred, and, when necessary, 2000 IU of hCG were injected to induce ovulation and obtain synchronization with donors.

Recipients were considered as in anestrous or transition when, after three ultrassonographic evaluations, follicles under development would persist and/or regress, in the absence of a corpus luteum. Acyclic mares were intramuscularly treated with estradiol cypionate $\left(\mathrm{ECP}^{\circledR}\right.$ Pfizer Saúde Animal, São Paulo, SP, Brazil) during three consecutive days, using decreasing doses of, respectively, $10 \mathrm{mg}, 6 \mathrm{mg}$ and $4 \mathrm{mg}$. If these mares showed endometrial edema development as a result of this estrogen treatment, $1500 \mathrm{mg}$ of long-acting progesterone (P4LA150 ${ }^{\circledR}$ Laboratórios B.E.T., Rio de Janeiro, RJ, Brazil) were intramuscularly injected on the fourth day. Embryos were transferred to this group of mares, predominantly, during the first months of the breeding season. In order to evaluate the grade of uterine edema following estradiol cypionate treatment, uterine ecotexture was classified as proposed by De La Côrte et al. (1992). Mares showing strong edema and clearly defined endometrial folds throughout the whole uterus were considered suitable for long-acting progesterone treatment.

After being successfully washed, embryos were drawn into sterile artificial insemination pipettes and transferred

Table 1 - Classification system used to grade quality of equine embryos

\begin{tabular}{ll}
\hline Grade & Description \\
\hline Grade I & Excellent - ideal embryo, spherical, with cells of uniform size, color, and texture. \\
Grade II & Good - minor imperfections such as a few extruded blastomeres, irregular shape or trophoblastic separation. \\
Grade III & Fair - definite but not severe problems, presence of extruded blastomeres, degenerate cells, or collapsed blastocoele. \\
Grade IV & Poor - severe problems, collapsed blastocoele, numerous extruded blastomeres, degenerate cells, but with a viable \\
Grade V & appearing embryonic mass. \\
Adapted from McKinnon \& Squires (1988).
\end{tabular}

R. Bras. Zootec., v.41, n.3, p.607-611, 2012 
using the nonsurgical transcervical method, as proposed by Riera et al. (1993). In this study, only fresh Grade I embryos, between six and eight days of age, were transferred. Recipients that did not become pregnant after the fifth inovulation were discarded. Cyclic recipients received embryos between the third and ninth day post-ovulation. Embryos were transferred to acyclic recipients between the third (P3) and sixth (P6) day after the first long-acting progesterone injection (P0). Acyclic mares were once more treated with $1.500 \mathrm{mg}$ of long-acting progesterone at embryo transfer.

Recipients were diagnosed as pregnant through ultrassonography, when embryos reached at least twelve days of age. Pregnant recipients were monitored every seven days, in order to detect possible embryonic losses. Acyclic pregnant mares received weekly injections containing $1500 \mathrm{mg}$ of long-acting progesterone until 100 days of pregnancy.

Statistical analysis was performed using InStat 3 program. The following parameters were evaluated: pregnancy rates after embryo transfer and embryo mortality rates of cyclic and acyclic recipients. Likewise, the present study evaluated, on acyclic recipients, the influence of the interval between the onset of long-acting progesterone treatment and embryo transfer on pregnancy and embryo mortality rates. These dichotomous qualitative variables were compared in contingency tables and analyzed using the Chi-square test $\left(\chi^{2}\right)$. Significance levels were set as $\mathrm{P}<0.05$.

\section{Results and Discussion}

From all 1506 performed embryo recovery attempts (Table 2), 59.36\% were positive (894/1506). A total of 1134 embryos were obtained, leading to a $75.30 \%(1134 / 1506)$ embryo recovery rate.

The percentage of positive flushes in the present study (59.36\%) is similar to the ones reported using fresh and cooled semen (Squires et al., 2003). The age of resident donors at the clinic, which averaged 14.8 years at certain periods, can be accounted for reducing this rate. According to previously published studies, older mares show lower embryo recovery rates (Ball et al., 1989; Squires et al., 2003).

Table 2 - Data on obtained embryos and embryo recovery attempts

\begin{tabular}{lc}
\hline Evaluated data & Total/Percentage \% \\
\hline Embryo recovery attempts & 1506 \\
Positive embryo recovery attempts & $59.36 \%(894 / 1506)$ \\
Embryos recovered & 1134 \\
Embryos recovered/positive attempts & $1.27(1134 / 894)$ \\
Embryos recovered/attempts performed & $75.30 \%(1134 / 1506)$ \\
\hline
\end{tabular}

Out of all 1134 embryos recovered, 964 were classified as of Grade I. Upon transfer, 458 recipients became pregnant (47.51\%; 458/964). Two hundred forty-one embryos were transferred to acyclic and 723 to cyclic recipients, resulting in pregnancy rates of, respectively, 57.68\% (139/241) and 44.12\% (319/723). Acyclic mares treated with long-acting progesterone showed higher pregnancy rates $(\mathrm{P}<0.0003)$ than cyclic mares. On the other hand, similar embryo mortality rates $(\mathrm{P}>0.05)$ were observed in acyclic $(11.51 \%$ - $16 / 139)$ and cyclic recipients $(9.72 \%$ - 31/319) (Table 3$)$.

In the present study, the pregnancy rate obtained (47.51\%) was lower than the ones reported using nonsurgical transcervical embryo transfer, such as 70\% (Squires et al., 1999), 82.9\% (Foss et al., 1999), 65.7\% (Carnevale et al., 2000), 74.9\% (Fleury et al., 2001) and 82.5\% (Jasko, 2002). It is known that the proper management of recipients is the major factor for success in embryo transfer programs (Squires et al., 1999; Losinno \& Alvarenga, 2006). The low recipient:donor ratio in this study might have been responsible for the unsatisfactory pregnancy rates obtained, making recipient selection harder. According to Carnevale et al. (2000) and Alonso et al. (2008), proper selection of recipients dramatically influences pregnancy rates.

In the present study, acyclic recipients under progesterone treatment showed higher pregnancy rates than cyclic ones (44.12\% versus $57.68 \%$, respectively). In previously published studies, acyclic recipients presented either similar (Carnevale et al., 2000; Rocha Filho et al., 2004) or lower pregnancy rates (Riera et al., 2008).

Upon evaluation of a commercial embryo transfer program in Argentina, Riera et al. (2008) found that progesterone-treated acyclic recipients showed satisfactory pregnancy rates, even though they were lower than the one obtained using cyclic mares (58\% versus $74 \%$ ). In their study, however, embryo transfer to recipients under hormonal treatment was conducted during the last months of the breeding season. It is possible that, at that time, less suitable recipients were available and, therefore, selected for embryo transfer.

To our knowledge, the results obtained in the present study, in which acyclic mares showed higher pregnancy rates after embryo transfer, have not yet been reported in

Table 3 - Pregnancy and embryo mortality rates in cyclic and acyclic recipients

\begin{tabular}{lcc}
\hline Group evaluated & $\begin{array}{c}\text { Pregnancy } \\
\text { rate }(\%)\end{array}$ & $\begin{array}{c}\text { Embryo mortality } \\
\text { rate }(\%)\end{array}$ \\
\hline Cyclic recipients & $44.12 \%$ a $(319 / 723)$ & $9.72 \%(31 / 319)$ \\
Acyclic recipients & $57.68 \%$ b $(139 / 241)$ & $11.51 \%(16 / 139)$ \\
Total & $47.51 \%(458 / 964)$ & $10.26 \%(47 / 458)$ \\
\hline a,b - Different letters within columns indicate significant difference $\left(\mathrm{P}<0.05-\chi^{2}\right)$.
\end{tabular}


the literature. Some hypothesis may justify this finding. The hormonal treatment of acyclic recipients allows that a superior number of mares be suitable for embryo transfer, improving selection and increasing success rates. Also, some cyclic recipients might suffer from premature luteolysis during transcervical embryo transfer, due to cervical manipulation. Kask et al. (1997) found that transcervical embryo transfer procedures can reduce plasmatic progesterone concentrations. Similar reductions have been detected by Handler et al. (2003), when diestrous mares were submitted to cervical dilatation. More recently, McCue et al. (2008) observed the occurrence of complete luteolysis in $6.2 \%$ of the mares submitted to transcervical embryo transfer. On the other hand, plasmatic progesterone concentrations of acyclic recipients are not influenced by cervical manipulation, since they are dependent on an exogenous source.

Embryo mortality rates of cyclic (9.72\%) and acyclic (11.51\%) recipients were similar to those obtained by Imel et al. (1981), of 13\%. Similar embryo mortality rates between cyclic and acyclic recipient mares had been previously observed by Rocha Filho et al. (2004). Carnevale et al. (2000) identified that acyclic recipients under progestin treatment suffered from higher embryo mortality rates (30\% versus $14.5 \%)$, which, however, did not differ statistically. During the latter, mares were not treated with estrogen prior to progestin administration. Further studies are necessary to determine whether pre-treatment with estrogen influences pregnancy and embryo mortality rates of acyclic mares.

Acyclic recipients on P3, P4, P5 and P6 showed similar $(\mathrm{P}>0.05)$ pregnancy rates at 12 days: $51.28 \%(20 / 39)$; 58.93\% (33/56); 60.53\% (46/76) and 58.57\% (41/70), respectively. The interval between the onset of longacting progesterone treatment and embryo transfer did not affect pregnancy rates in acyclic recipient mares. Acyclic recipients on P3, P4, P5 and P6 showed embryo mortality rates (Table 4 ) of $20.00 \%$ (4/20), $12.12 \%$ (4/33), 2.17\% (1/46) and $17.07 \%$ (7/41), respectively. Recipients on P3, P4 and $\mathrm{P} 6$ showed similar embryo mortality rates $(\mathrm{P}>0.05)$. However, pregnant recipients submitted to an embryo transfer procedure on $\mathrm{P} 5$ showed lower $(\mathrm{P}<0.02)$ embryo mortality rates than $\mathrm{P} 3$ and $\mathrm{P} 6$. Moreover, $\mathrm{P} 4$ recipients tended to suffer higher embryo mortality rates than P5 $(\mathrm{P}=0.07)$.

In their study, Rocha Filho et al. (2004) obtained contrasting results, since mares on P5 and P6 suffered similar embryo loss rates of $19.2 \%$ and $16.0 \%$, respectively. This study used a different progesterone protocol, limiting comparisons. On this regard, Carnevale et al. (2000) verified that cyclic recipient on the fifth day post-ovulation demonstrated lower embryo mortality rates.

Table 4 - Pregnancy and embryo mortality rates of acyclic recipients, according to the interval (in days) between the onset of progesterone treatment (P0) and embryo transfer

\begin{tabular}{lccc}
\hline Day of embryo transfer & Number of transferred embryos & Pregnancy rate & Embryo mortality rate \\
\hline Recipient on P3 & 39 & $51.28 \% a(20 / 39)$ & $20.00 \% a(4 / 20)$ \\
Recipient on P4 & 56 & $58.93 \% a(33 / 56)$ & $12.12 \% a, b(4 / 33)$ \\
Recipient on P5 & 76 & $60.53 \% a(46 / 76)$ & $2.17 \%$ b $(1 / 46)$ \\
Recipient on P6 & 70 & $58.57 \% a(41 / 70)$ & $17.07 \% a(7 / 41)$ \\
\hline
\end{tabular}

a,b - Different letters within columns indicate significant difference $\left(\mathrm{P}<0.05-\chi^{2}\right)$

\section{Conclusions}

Acyclic recipients under long-acting progesterone treatment can be used in equine embryo transfer programs with higher pregnancy and similar embryo mortality rates, when compared with cyclic recipients. Long-acting progesteronetreated acyclic recipients can be used from the third to the sixth day post-injection, with similar pregnancy rates.

\section{Acknowledgements}

The authors would like to thank Clínica Equus Veterinária and Fopesq/PROPPi/UFF for the financial support, and PIBIC/CNPq for the scholarship granted.

\section{References}

ALONSO, M.A. Seleção, manejo e fatores que influenciam as taxas de prenhez em éguas receptoras de embriões. Acta Scientiae Veterinariae, v.36, Supl. 2, p.207-214, 2008.

BALL, B.A.; LITTLE, T.; WEBER, J.A. et al. Survival of day-4 embryos from young, normal and aged, subfertile mares after transfer to normal recipient mares. Journal of Reproduction and Fertility, v.85, n.1, p.187-209, 1989.

CARNEVALE, E.M.; RAMIREZ, R.J.; SQUIRES, E.L. et al. Factors affecting pregnancy rates and early embrionic death after equine embryo transfer. Theriogenology, v.54, n.6, p.965-979, 2000.

DE LA CÔRTE, F.D.; ALDA, J.L.; LUZ, I.N.C. et al. Descrição ecográfica do útero e dos ovários durante o ciclo estral. Ciência Rural, v.22, n.2, p.209-212, 1992.

FLEURY, J.J.; ALVARENGA, M.A.; FIGUEIREDO COSTA, J.B. Transferência de embriões em eqüinos - Nota prévia. In: CONGRESSSO BRASILEIRO DE REPRODUÇÃO ANIMAL, 7. 
1987. Belo Horizonte. Anais... Belo Horizonte: Colégio Brasileiro de Reprodução Animal, 1987. p.40.

FLEURY, J.J. Avaliação da eficiência do meio Ham F-10 acrescido com BSA e tamponado com Hepes na manutenção de embriões eqüinos, a temperatura de 15 a $18^{\circ} \mathrm{C}$, por diferentes períodos de tempo. 2002. 86f. Dissertação (Mestrado em Medicina Veterinária) - UNESP, Botucatu.

FLEURY, J.J.; PINTO, A.J.; MARQUES, A. et al. Fatores que afetam a recuperação embrionária e os índices de prenhez após transferência transcervical em eqüinos da raça Mangalarga, Brazilian Journal Veterinary Research Animal Science, v.38, n.1, p.29-33, 2001.

FOSS, R.; WIRTH, N.; SCHILTZ, P. et al. Nonsurgical embryo transfer in a private practice (1998). American Association of Equine Practioners, v.45, p.210-212, 1999.

GOFF, A.K. Embryonic signals and survival. Reprodution Domestic Animals, v.37, n.1, p.133-139, 2002.

HENRY, M.; MEIRA, C.; OLIVEIRA, M.M.F. Transferência não cirúrgica de embriões em eqüídeos. In: CONGRESSSO BRASILEIRO DE REPRODUÇÃO ANIMAL, 7., 1987, Belo Horizonte. Anais... Belo Horizonte: Colégio Brasileiro de Reprodução Animal, 1987. p.74.

HINRICHS, K.; SERTICH, P.L.; CUMMINGS, M.R. et al. Pregnancy in ovariectomized mares achieved by embryo transfer: a preliminary study. Equine Veterinary Journal, Suppl 3, p.74-75, 1985.

IMEL, K.J.; SQUIRES, E.L.; ELSDEN, R.P. et al. Collection and transfer of equine embryos. Journal of American Veterinary Medical Association, v.179, n.8, p.987-991, 1981.

JASKO, D.J. Comparison of pregnancy rates following nonsurgical transfer of day 8 equine embryos using various transfer devices. Theriogenology, v.58, n.2-4, p.713-715, 2002.

KASK, K.; ODENSVIK, K.; KINDAHL, H. Prostaglandin F2a release associated with an embryo transfer procedure in the mare. Equine Veterinary Journal, v.29, n.4, p.286-289, 1997.

LOSINNO, L.; AVARENGA, M.A. Fatores críticos em programas de transferência de embriões em eqüinos no Brasil e Argentina. Acta Scientiae Veterinariae, v.34, Supl. 1, p.39-49, 2006.
McCUE, P.; DelUCA, M.; PATTEN M. et al. Effect of a sham transcervical embryo transfer and/or altrenogest administration on plasma progresterone concentrations in recipient mares. In: INTERNATIONAL SYMPOSIUM ON EQUINE EMBRYO TRANSFER, 7., 2008, Cambridge. Abstract Book... Cambridge: Dorothy Russell Havemeyer Foundation, 2008. p.73-74.

McKINNON, A.O.; SQUIRES, E.L. Morphologic assessment of the equine embryo. American Veterinary Medical Association, v.192, n.3, p.401-406, 1988b

McKINNON, A.O.; SQUIRES, E.L.; CARNEVALE, E.M. et al. Ovariectomized steroid-treated mare as embryo transfer recipients and as a model to study the role of progestins in pregnancy maintenance. Theriogenology, v.29, n.5, p.1055-1063, 1988a

RIERA, F.L.; McDONOUGH, J. Commercial embryo transfer in polo ponies in Argentina. Equine Veterinary Journal, v.15, p.116-1118, 1993

RIERA, F.L.; ROLDÁN, J.E.; HINRICHS, K. Pregnancy rate after embryo transfer in ovulating versus progesterone treated-anestrous recipient mares in a comercial embryo transfer programme. In: INTERNATIONAL SYMPOSIUM ON EQUINE EMBRYO TRANSFER, 7., 2008, Cambridge. Abstract Book... Cambridge: Dorothy Russell Havemeyer Foundation, 2008. p.79-80.

ROCHA FILHO, A.N.; PESSÔA, M.A.; GIOSO, M.M. et al. Transfer of equine embryos into anovulatory recipients supplemented with short or long acting progesterone. Animal Reproduction, v.1, n.1, p.91-95, 2004.

SQUIRES, E.L.; CARNEVALE, E.M.; MCCUE, P.M. et al. Embryo technologies in the horse. Theriogenology, v.59, p.151-170, 2003.

SQUIRES, E.L.; McCUE, P.M.; VANDERWALL, D. The current status of equine embryo transfer. Theriogenology, v.51, n.1, p.91-104, 1999.

WILKER, C.; DAELS, P.F.; BURNS, P.J. et al. Progesterone therapy during early pregnancy in mares. In: AAEP ANNUAL CONVEntion, 37., 1991, San Francisco. Proceedings... San Francisco: 1991. v.37, p.161-172. 